\title{
Quality indicators for the assessment of pain clinic care
}

Citation for published version (APA):

de Meij, N. (2018). Quality indicators for the assessment of pain clinic care: a step forward? Quality from professionals and pain patients' perspective (QiPPP). [Doctoral Thesis, Maastricht University]. Datawyse / Universitaire Pers Maastricht. https://doi.org/10.26481/dis.20180607pm

Document status and date:

Published: 01/01/2018

DOI:

10.26481/dis.20180607pm

Document Version:

Publisher's PDF, also known as Version of record

\section{Please check the document version of this publication:}

- A submitted manuscript is the version of the article upon submission and before peer-review. There can be important differences between the submitted version and the official published version of record.

People interested in the research are advised to contact the author for the final version of the publication, or visit the DOI to the publisher's website.

- The final author version and the galley proof are versions of the publication after peer review.

- The final published version features the final layout of the paper including the volume, issue and page numbers.

Link to publication

\footnotetext{
General rights rights.

- You may freely distribute the URL identifying the publication in the public portal. please follow below link for the End User Agreement:

www.umlib.nl/taverne-license

Take down policy

If you believe that this document breaches copyright please contact us at:

repository@maastrichtuniversity.nl

providing details and we will investigate your claim.
}

Copyright and moral rights for the publications made accessible in the public portal are retained by the authors and/or other copyright owners and it is a condition of accessing publications that users recognise and abide by the legal requirements associated with these

- Users may download and print one copy of any publication from the public portal for the purpose of private study or research.

- You may not further distribute the material or use it for any profit-making activity or commercial gain

If the publication is distributed under the terms of Article $25 \mathrm{fa}$ of the Dutch Copyright Act, indicated by the "Taverne" license above, 
Summary 

The first chapter describes the impact and content of chronic pain and the (inter)national approaches to chronic pain in pain treatment services. Then, the concept of quality indicators and the importance of patient participation for the assessment of pain care are explained.

The quality of pain care is complex, and reflects not only the medical decisionmaking, but also the organisational structure and processes. Therefore, the need to define 'good quality pain care' is highly important. Quality indicators can be used to measure, compare, and improve the quality of care. A tripartite classification was proposed (Donabedian) to infer if 'the quality is good or not': structure indicators (settings in which care occurs), process indicators (what is actually done in giving care), and outcome indicators (the effect of healthcare on the health status of the patient or populations).

Since at the beginning of this study Dutch consensus concerning quality standards for the assessment of pain treatment services was not available, establishing such a consensus was regarded as essential. To achieve quality standards for the assessment of pain treatment services on a national level, consensus among target users is crucial. To obtain consensus from experts in the pain field as to which quality indicators (structure, process, and outcome) pain treatment services should adhere to is important. However, different perspectives on the quality of care may require different methods for $\mathrm{Q}$ I development. Professionals tend to put emphasis on professional standards, efficiency, and health outcomes. Patients often relate quality to hospitality issues such as waiting lists and patient centred communication, and practical performance of professionals. Consequently, this may have important implications for the assessment of quality pain care. Therefore, in addition to the perspective of professionals when assessing pain care quality, the participation of patients and the utilisation of the patients' specific expertise, based on their experience of pain care, is essential.

This thesis addresses the quality improvement developments for Dutch daily pain practice. This thesis aimed to set quality standards for the assessment of daily pain practice in Dutch pain treatment services from the perspective of patients and professionals. The thesis is divided in 2 consecutive parts. The first part focused on exploring the organisation (structure) of pain treatment services and the content of Dutch daily pain practice. The second part of this thesis concentrates on the development of structure, process and outcome indicators for the assessment of pain clinic care from the perspective of patients and professionals.

The research questions we have formulated are:

1. What is the number of pain treatment facilities, the content of organised, specialised pain care, and the adherence to the criteria of the internationally accepted guidelines for pain treatment services? 
2. What is the level of agreement between the 'highest standards of pain practice' of the World Institute of Pain and the 'recommendations for pain treatment services' of the International Association for the Study of Pain?

3. What expert-agreed list of quality indicators can be developed which could be used by pain treatment services to assess whether chronic pain patients were undergoing appropriate multidisciplinary diagnostics and receiving appropriate treatment?

4. From the perspective of patients suffering from chronic pain, which quality indicators can be developed to assess the quality of clinical pain care?

5. What is the usability, comprehensibility and validity of the QiPPP (Quality indicators Pain Patients Perspective) questionnaire in daily pain practices in the Netherlands?

The thesis describes five studies, starting with a descriptive study on the content of daily pain practice in the Netherlands (part 1), followed by four studies on developing and evaluating valid and acceptable quality indicators (part 2). The findings from this work were translated into a basis set of criteria for registered status of Dutch pain treatment services. Furthermore, quality indicators from the patients' perspective were developed, resulting in the QiPPP questionnaire.

Chapter 2 presents the adherence of Dutch pain treatment facilities to the criteria of the international accepted guidelines for pain treatment services. To obtain information about organisational aspects of Dutch pain treatment facilities and the content of their daily pain practice, we performed a questionnaire survey. The aim of the study was to evaluate the number of pain treatment facilities, the content of organised specialised pain care and adherence to the criteria of the internationally accepted guidelines for pain treatment services. In 2009, the questionnaire survey, based on the Recommendations for Pain Treatment Services of the International Association for the Study of Pain (IASP), was sent to the medical boards of all general hospitals in the Netherlands ( $n=94)$. The response rate was $86 \%(n=81)$. Of all hospitals, $88.9 \%(n=72)$ indicated to provide organised specialised pain care, which was provided by a pain management team in $86.1 \%(n=62)$, and by an individual specialist in $13.9 \%(n=10)$. Insight was obtained from pain treatment facilities in five different domains; the organisational structure of pain management, composition of the pain team, pain team practice, patient characteristics, and research and education facilities. Concluded was that although nearly $90 \%$ of all hospitals stated that organised specialised pain care was provided, only a few $(1.2 \%)$ hospitals could actually adhere to the criteria for pain treatment services of the IASP.

In chapter 3, the agreements between "high standards for pain practice" of the World Institute of Pain (WIP) and "recommendations for pain treatment services" established by the International Association for the Study of Pain (IASP) were analysed. Although the standards for highest pain practice of the WIP and the guidelines for pain treatment services of the IASP have been developed for different purposes, their common goal was to improve the quality of pain practice management. However, the existence of 
these various criteria and recommendations for pain centers gives rise to the question about differences and similarities between the criteria of the WIP and the IASP. Therefore, we analysed the level of agreement between those criteria. The aim was to describe levels of agreement (when both institutions highlighted the same criterion for a specific domain) between the high standards of pain practice of the WIP and the recommendations for pain treatment services of the IASP. With respect to the criteria of the WIP and the IASP (all aspects are included as published on the internet web-sites of the Institutions) we allocated the criteria in 7 quality domains: 1. Supervision, 2. Continuity of care, 3. Formation staff and patient load, 4. Quality policy, 5. Multidisciplinary, 6. Research and education, 7. Regionalization. Successively, we found agreement for 4 out of 7 quality domains between the standards of the WIP and the guidelines of the IASP: supervision, quality policy, research and education, and regionalization. Additionally, recommendations for future steps were made:

- Specify appropriate quality criteria for pain treatment facilities

- Achieve consensus among experts regarding the appropriate quality criteria

- Develop pain quality indicators

- Involve chronic pain patients in the development of pain quality indicators

- Apply the quality indicators for registration and/or certification of pain clinics and pain centers

In Chapter 4 quality indicators for the assessment and registration of Dutch pain treatment services were developed from the perspective of the professionals. The aim of the study was to develop an expert-agreed list of quality indicators applicable to Dutch pain treatment facilities. The list was also intended to be used as the basis for a set of criteria for registered status of pain treatment facilities. We conducted a 3-round Delphi study in collaboration with the Board of the Pain Section of the Dutch Society of Anaesthesiologists (NVA). Twenty-five quality indicators were selected as relevant to 2 types of pain treatment facilities, pain clinics and pain centers. The final expert-agreed list consisted of 22 quality indicators covering 7 quality domains: supervision, availability of care, staffing level and patient load, quality policy, multidisciplinarity, regionalization, and research and education. This set of quality indicators may facilitate organizational evaluation and improve insight into service quality from the perspectives of pain specialists and other health care professionals. Recommendations for improvements to the current set of quality indicators were made. In 2014, pain treatment facilities could appeal for a status as a pain clinic or pain center conform acquired quality. In 2018, no distinction was made between clinics and centres, with the only difference being the registered or non-registered status. Except proposals to improve some quality indicators in near future, the recommendation to involve patients in the development of quality indicators was made.

Chapter 5 describes the process of quality indicator development in partnership between patients and professionals. The aim of this study was to develop quality indica- 
tors from the perspective of patients with chronic pain for assessment of the care provided by a chronic pain clinic. This chapter shows the process of development of quality indicators in collaboration between patients and professionals. Quality as defined by patients with chronic pain was prioritised by consensus and transformed into quality indicators, resulting in the QiPPP questionnaire (Quality indicators Pain Patients' Perspective). The QiPPP questionnaire was tested on the formulation of sentences conform the Three-Step-Test-Interview (TSTI) by patients suffering from chronic pain. In consensus with patient organisations, 21 quality indicators were developed and divided into 11 quality domains. The QiPPP questionnaire included two classifications of the approaches to assessment, i.e., the process ( $n=18$ QI) and outcome ( $n=3$ QI) of pain care. Process quality indicators included contact between patient and physician, one central contact person for the patient, waiting time, pain team information, administration of pain questionnaire, attendance for work and rehabilitation, shared decision-making regarding treatment, and setting a treatment goal. Outcome quality indicators included achievement of treatment goal and treatment result, and the result of the pain care process.

In chapter 6 the result on the validation of the QiPPP questionnaire is presented. The objective of the study was to describe the usability, comprehensibility, and psychometric quality of the QiPPP questionnaire in daily pain practice. In addition to the QiPPP questionnaire items on process and outcome quality indicators, we evaluated sociodemographic, health, and pain-related data and questionnaire comprehensibility. Five participating pain clinics were each instructed to distribute 200 questionnaires among consecutive chronic pain patients who were currently under treatment in their pain clinic. To examine the dimensionality of the quality indicators, patient responses were analysed on the basis of reporting frequencies and findings of principal component analysis. For construct validation, case mix analysis was performed to measure the influence of certain patient characteristics on the results of the questionnaire according our hypotheses. A total of 547 populated QiPPP questionnaires (response rate 58.9\%) were analysed. The mean score for patient comprehensibility was $8.6 \pm 1.4$. The final QiPPP questionnaire included 21 quality indicators (18 process; 3 outcome) distributed over 7 domains. To define the influence of patient characteristics on the quality indicators and to compare hospitals with different settings, the case mix analysis for each quality indicator was assessed. The results revealed that sex, general health status, education level, duration of pain complaint, and number of pain clinic visits were significantly associated with the reported quality indicator scores. Based on all findings the QiPPP questionnaire was found to be useful and understandable by patients with chronic pain and of sufficient psychometric quality.

In chapter 7 we summarised the main findings, reflected on strengths and limitations and reported the conclusions and recommendations. This thesis started with an evalua- 
tion of pain practice variation, and thereafter, the development of the 'first Dutch consensus on quality indicators' for the organisation of Dutch pain treatment services.

A first step forward has been made here; the structure indicators identified in this study comprise the first list of quality indicators for the registration of pain treatment services with the Dutch Society of Anaesthesiologists (NVA). In 2014, pain treatment facilities could appeal for a status as a pain clinic or pain centre if they could prove to be adhering to the acquired quality indicators. In 2018, no distinction was made between clinics and centres, with the only difference being the registered or non-registered status. This does not benefit the transparency for referral healthcare providers and patients. To emphasize the distinction between registered and non-registered pain treatment services, the quality indicators concerning the use of a 'multidisciplinary approach' need to be improved, and indicators related to 'shared decision making' need to be included in the quality indicators of the NVA.

A second step forward was the development of quality indicators from the perspective of patients suffering from chronic pain, which resulted in the development of the QiPPP questionnaire. The QiPPP questionnaire was found to be useful and comprehensible by patients in daily pain practice. These quality indicators may play an important role in the multidisciplinary standard care for chronic pain (Pain Alliance Netherlands). In this context, the quality indicators from the QiPPP questionnaire can play an important role in providing a broader perspective within integrated care. Integration of the quality indicators from patients' perspective (QiPPP questionnaire) into the national quality system of chronic pain care (NVA) seems the next important step to be taken. Therefore, a partnership between patients and professionals is fundamental. Together, the basis set with structure indicators from professionals and the process and outcome quality indicators from patients perspective, form a first set of structure, process, and outcome quality indicators for the quality assessment of the care provided in chronic pain clinics. We recommend for the future, to develop outcome indicators on top of the available structure and process indicators, in the same robust manner and in partnership with the patients, to further improve value of care for patients and physicians. 



\section{Samenvatting}



Het eerste hoofdstuk beschrijft de impact van chronische pijn in het dagelijkse leven, een definitie van chronische pijn en de internationale en nationale benaderingen van chronische pijn vanuit pijn behandel faciliteiten. Vervolgens wordt het concept en het belang van kwaliteitsindicatoren voor de beoordeling van pijnzorg toegelicht. De kwaliteit van pijnzorg is complex en reflecteert niet alleen aan medische besluitvorming maar ook aan organisatiestructuur- en processen. Daarom is het belangrijk om 'goede kwaliteit van pijnzorg' te definiëren. Kwaliteitsindicatoren kunnen worden gebruikt om de kwaliteit van zorg te meten, te vergelijken en te verbeteren. Een tripartiete classificatie (Donabedian) om te bepalen of de kwaliteit 'goed is of niet' is als volgt: structuurindicatoren (de wijze waarop organisatie van zorg plaatsvindt), procesindicatoren (wat er feitelijk wordt gedaan bij het geven van zorg) en uitkomstindicatoren (het effect van gezondheidszorg op de gezondheidsstatus van de patiënt of populaties).

Aangezien er geen Nederlandse consensus bestaat over kwaliteitsnormen voor de beoordeling van pijnbehandel faciliteiten, is het vaststellen van een dergelijke consensus essentieel. Om kwaliteitsnormen voor de beoordeling van pijnbehandel faciliteiten op nationaal niveau te bereiken, is consensus tussen doelgebruikers cruciaal. Daarvoor is het belangrijk om consensus te bereiken tussen deskundigen op het gebied van pijn, aan welke kwaliteitsindicatoren (structuur, proces en uitkomst) pijnbehandel faciliteiten moeten voldoen. Verschillende perspectieven op de kwaliteit van zorg kunnen echter verschillende methoden voor kwaliteits ontwikkeling vereisen. Professionals neigen eerder de nadruk te leggen op professionele normen, met name efficiëntie en gezondheidsresultaten. Patiënten belichten meer de kwaliteit met communicatievaardigheden (contact tussen patiënt en arts) en praktische prestaties van professionals. Dit kan dus belangrijke implicaties hebben voor de beoordeling van pijngeneeskunde van hoge kwaliteit. Daarom is, naast het perspectief van professionals bij het beoordelen van de kwaliteit van pijnzorg, participatie van patiënten met specifieke expertise op basis van hun ervaring met pijnzorg essentieel.

Dit proefschrift gaat in op de ontwikkelingen op het gebied van kwaliteitsverbetering voor de dagelijkse Nederlandse pijnpraktijk. Het proefschrift is verdeeld in 2 opeenvolgende delen. Het eerste deel is gericht op het verkennen van de organisatie (structuur) en praktijk van Nederlandse pijnbehandel faciliteiten. Het tweede deel van dit proefschrift concentreert zich op de ontwikkeling van structuur-, proces- en uitkomstindicatoren voor de beoordeling van pijnkliniekzorg vanuit het perspectief van professionals en patiënten. Dit proefschrift heeft als doel kwaliteitsnormen te stellen voor de beoordeling van de dagelijkse pijnpraktijk in Nederlandse pijnbehandel faciliteiten vanuit het perspectief van professionals en patiënten.

De geformuleerde onderzoeksvragen zijn:

1. Wat is het aantal pijnbehandel faciliteiten, de inhoud van georganiseerde, gespecialiseerde pijnzorg en de naleving van criteria op de internationaal aanvaarde richtlijnen ten aanzien van pijnbehandelcentra? 
2. Wat is het niveau van overeenstemming tussen de 'hoogste normen van de pijnpraktijk' van het World Institute of Pain en de 'richtlijnen voor pijnbehandelcentra' van de International Association for the Study of Pain?

3. Welke expert-consensus lijst van kwaliteitsindicatoren kan worden ontwikkeld die door pijnbehandel faciliteiten kunnen worden gebruikt om te beoordelen of chronische pijnpatiënten passende multidisciplinaire diagnostiek ondergingen en een passende behandeling ontvingen?

4. Welke kwaliteitsindicatoren vanuit het perspectief van patiënten met chronische pijn kunnen worden ontwikkeld om de kwaliteit van klinische pijnzorg te beoordelen.

5. Wat is de bruikbaarheid, begrijpelijkheid en validiteit van de KwiPPP vragenlijst (Kwaliteitsindicatoren PijnPatiënten Perspectief) in de dagelijkse pijnpraktijken in Nederland?

Deze thesis beschrijft vijf studies, beginnende met een beschrijvende studie over de organisatie en inhoud van de Nederlandse dagelijkse pijnpraktijk (deel 1), gevolgd door vier studies over de ontwikkeling en evaluatie van gevalideerde en geschikte indicatoren (deel 2). De bevindingen werden vertaald naar een basisset met criteria voor de registratie van Nederlandse pijnbehandel faciliteiten. Daarnaast werden kwaliteitsindicatoren ontwikkeld, welke hebben geresulteerd in de KwiPPP vragenlijst.

Hoofdstuk 2 presenteert de naleving van de internationaal geaccepteerde richtlijnen voor pijnbehandelcentra binnen de Nederlandse pijnbehandel faciliteiten. Om inzicht te krijgen in de organisatie en de dagelijkse praktijk binnen de pijnbehandel faciliteiten is geëvalueerd middels een vragenlijst. Het doel van de studie was om inzicht te krijgen in het aantal pijnbehandel faciliteiten, de organisatie van gespecialiseerde pijnzorg en de naleving op de internationaal geaccepteerde richtlijnen voor pijnbehandelcentra. In 2009 werd de vragenlijst, gebaseerd op de richtlijnen voor pijnbehandelcentra, verstuurd naar de raden van bestuur van alle Nederlandse ziekenhuizen $(n=94)$. De response was $86 \%(n=81)$. Van alle ziekenhuizen, gaf $88.9 \%(n=72)$ aan georganiseerde specialistische pijnzorg te leveren, verstrekt door een pijnmanagementteam in $86.1 \%(n=62)$ en door een individuele specialist in $13.9 \%(n=10)$. Inzicht is verkregen binnen de pijnbehandel faciliteiten in 5 verschillende domeinen; de organisatie structuur van pijnmanagement, de samenstelling van een pijnteam, de soorten behandelingen van een pijnteam, patiënten karakteristieken en onderzoek en opleidingsfaciliteiten. Geconcludeerd werd dat, alhoewel bijna 90\% van de ziekenhuizen aangeeft georganiseerde en gespecialiseerde pijnzorg te leveren, maar weinig (1.2\%) van de ziekenhuizen konden voldoen aan de richtlijnen voor pijnbehandelcentra van de International Association for the Study of Pain (IASP).

Hoofdstuk 3 behandelt de overeenkomsten tussen de 'hoge normen voor pijn praktijk' van de World Institute of Pain (WIP) en de 'richtlijnen voor pijnbehandelcentra' van de 
International Association for the Study of Pain (IASP). Hoewel ze werden ontwikkeld voor verschillende doeleinden, de overeenkomst is dat ze beide dienen om de kwaliteit van pijnzorg te verbeteren. Echter, het bestaan van verschillende criteria en richtlijnen geeft te denken en is aanleiding om te kijken naar verschillen en overeenkomsten tussen de WIP en de IASP. Het uiteindelijke doel van deze studie was om te kijken naar het niveau van overeenkomst van criteria (welke criteria binnen een bepaald kwaliteitsdomein worden door beide instituten benadrukt). Met respect voor alle criteria van de WIP en de IASP (alle criteria zijn terug te vinden op de website van de instituten), hebben we de criteria verdeeld in 7 domeinen: 1. Supervisie, 2. Continuïteit van zorg, 3. Formatie staf en aantal (nieuwe) patiënten, 4. Kwaliteits beleid, 5. Multidisciplinariteit, 6. Onderzoek en opleiding en 7. Regionalisatie. Achtereenvolgens zijn 4 overeenkomsten gevonden tussen de criteria van de WIP en de IASP: supervisie, kwaliteits beleid, onderzoek en opleiding en regionalisatie. Voor vervolg stappen werden de volgende aanbevelingen gedaan:

- Specificeren van 'goede' kwaliteits criteria voor pijnbehandel faciliteiten

- Consensus bereiken onder experts met betrekking tot deze kwaliteits criteria

- Ontwikkeling van pijn kwaliteitsindicatoren

- Betrekken van patiënten in de ontwikkeling van pijn kwaliteitsindicatoren

- Geschikt maken van de indicatoren voor registratie en certificering van pijnklinieken en pijncentra

In hoofdstuk 4 werden kwaliteits indicatoren ontwikkeld voor de registratie van pijnbehandel faciliteiten vanuit het perspectief van professionals. Het doel van de studie was om een expert-consensus lijst met kwaliteitsindicatoren te ontwikkelen voor pijnbehandel faciliteiten. De intentie was om de lijst ook te gebruiken als een basisset (kwaliteits eis) voor de registratie van pijnbehandel faciliteiten. In samenwerking met het bestuur van de pijnsectie van de Nederlandse Vereniging voor Anesthesiologie (NVA) is een 3ronden Delphi studie uitgevoerd. Vijfentwintig kwaliteitsindicatoren werden geselecteerd als zijnde relevant voor 2 type pijnbehandel faciliteiten: pijnkliniek en pijncentrum. De uiteindelijke lijst bevatte 22 kwaliteitsindicatoren binnen 7 kwaliteits domeinen: 1. Supervisie, 2. Continuïteit van zorg, 3. Formatie staf en aantal (nieuwe) patiënten, 4. Kwaliteitsbeleid, 5. Multidisciplinariteit, 6. Onderzoek en opleiding, 7. Regionalisatie. Vanaf 2014 konden pijnbehandel faciliteiten zich registreren conform de kwaliteitseisen. Vanaf 2018 is geen onderscheid meer tussen de 2 typen pijnbehandel faciliteiten maar alleen tussen geregistreerd en niet-geregistreerde status. Naast aanbevelingen voor het verbeteren van de basisset in de toekomst, werd geadviseerd om patienten te betrekken bij de ontwikkeling van kwaliteitsindicatoren.

Hoofdstuk 5 beschrijft het proces van de kwaliteitsindicatoren ontwikkeling in samenwerking met patiënten en professionals. Het doel van de studie was om kwaliteitsindicatoren te ontwikkelen vanuit het perspectief van de patiënt met chronische pijn voor evaluatie van pijnzorg binnen de pijnbehandel faciliteiten. Dit hoofdstuk 
laat het proces van deze kwaliteitsindicatoren ontwikkeling zien tussen patiënten en professionals. Kwaliteitscriteria gedefinieerd door patiënten en geprioriteerd in consensus werden getransformeerd naar kwaliteitsindicatoren. Dit resulteerde in de KwiPPP (Kwaliteits indicatoren vanuit Pijn Patiënten Perspectief) vragenlijst. De KwiPPP vragenlijst is getest door patiënten met chronische pijn op de formulering van de vragen door middel van de Three-Step-Test-Interview (TSTI). In concordantie met de patiëntenorganisatie zijn 21 kwaliteitsindicatoren ontwikkeld verdeeld over 11 kwaliteits domeinen. De KwiPPP vragenlijst omvatte twee classificaties met betrekking tot evaluatie, namelijk proces $(n=18)$ en uitkomst $(n=3)$ van pijnzorg. De proces kwaliteitsindicatoren omvatten: 1. Patiënt - behandelaar contact, 2. Eén centraal contact persoon voor de patiënt, 3. Wachttijden, 4. Pijn team informatie, 5. Pijnvragenlijst, 6. Aandacht voor werk- en revalidatie, 7. Samen besluiten (shared-desicion) met betrekking tot behandeling, 8. Stellen van een behandeldoel. De uitkomst kwaliteits indicatoren omvatten: 1. Behaalde behandeldoel, 2. Behandel resultaat en 3. Resultaat van het hele behandel proces.

Hoofdstuk 6 geeft de resultaten van de validatie van de KwiPPP vragenlijst weer. Het doel van het onderzoek was om het (dagelijks) gebruik, de begrijpbaarheid en de psychometrische kwaliteit (psychologische eigenschappen en karakteristieken) van de KwiPPP vragenlijst in de dagelijkse praktijk te beschrijven. Naast de QiPPP-vragenlijst items over proces- en uitkomstkwaliteitsindicatoren, evalueerden we sociodemografische, gezondheids- en pijn gerelateerde gegevens en de begrijpelijkheid van de vragenlijst. Vijf deelnemende ziekenhuizen werden geïnstrueerd om ieder $200 \mathrm{KwiPPP}$ vragenlijsten te verspreiden onder willekeurige patiënten met chronische pijn onder behandeling. Om de dimensionaliteit van de kwaliteitsindicatoren te onderzoeken, werden de responsen van de patiënten geëvalueerd en de bevindingen van de principal component analyse (PCA, factor analyse) geanalyseerd. Voor constructvalidatie werd een case-mixanalyse uitgevoerd, om de invloed van patiëntkenmerken te meten aan de hand van onze hypothesen over de resultaten van de vragenlijst. Een totaal van 547 KwiPPP-vragenlijsten (responspercentage 58.9\%) werden geanalyseerd. De gemiddelde score voor begrijpelijkheid (vragenlijst) van de patiënt was $8.6 \pm 1.4$. De definitieve KwiPPP-vragenlijst omvatte 21 kwaliteitsindicatoren (18 proces, 3 uitkomsten) verdeeld over 7 kwaliteits domeinen. De invloed van de algemene gezondheidstoestand, opleiding, geslacht, duur van de pijnklachten en het aantal pijnkliniekbezoeken werden geëvalueerd ten aanzien van de resultaten van de vragenlijst. Op basis van alle bevindingen werd de KwiPPP vragenlijst bruikbaar en begrijpelijk bevonden door patiënten met chronische pijn en van voldoende psychometrische kwaliteit.

Hoofdstuk 7 bevat een samenvatting van de belangrijkste bevindingen uit de studies en reflectie op sterke en zwakke punten. Daarnaast werden conclusies getrokken en aanbevelingen voor de toekomst gedaan. De thesis is gestart met een evaluatie naar 
praktijkvariatie gevolgd door de ontwikkeling van de 'Eerste Nederlandse kwaliteitsindicatoren' voor de organisatie van Nederlandse pijnbehandel faciliteiten.

Een eerste stap vooruit is gemaakt: de structuurindicatoren voorkomend uit de studie vormen de basis voor een eerste basislijst met kwaliteitsindicatoren (kwaliteitseisen) voor de registratie van pijnbehandel faciliteiten geaccordeerd door de Nederlandse Vereniging van Anesthesiologen (NVA). Vanaf 2014 kunnen pijnbehandel faciliteiten opteren voor een status van pijnkliniek of pijncentrum indien voldaan aan de bijbehorende kwaliteitseisen. Vanaf 2018 wordt geen verschil meer gemaakt tussen pijnkliniek en pijncentrum, maar alleen de status tussen geregistreerd en nietgeregistreerd volgens de normen van de NVA.

Een tweede stap vooruit is de ontwikkeling van kwaliteitsindicatoren vanuit het perspectief van patiënten met chronische pijn. Dit resulteerde in de KwiPPP (QiPPP) vragenlijst. De KwiPPP vragenlijst werd bruikbaar en begrijpelijk gevonden door patiënten. Deze kwaliteitisindicatoren kunnen een belangrijke rol spelen binnen de multidisciplinaire standaardzorg voor chronische pijn (P.A.I.N alliance Nederland); in deze context (integrale zorg) is voor de kwaliteitisindicatoren een bredere rol weggelegd.

Integratie van de kwaliteitsindicatoren vanuit patiëntenperspectief binnen het nationale kwaliteitssysteem van de NVA is de volgende stap. Hiervoor is een gelijkwaardige samenwerking nodig tussen zorgprofessionals en patiënten. Gezamenlijk, vormt de basisset met structuur indicatoren vanuit het perspectief van professionals en de proces- en uitkomstindicatoren vanuit patiëntenperspectief een eerste basisset met kwaliteitsindicatoren voor de evaluatie van pijnzorg in van een pijnbehandel faciliteit. Om 'waarde gedreven zorg' verder te ontwikkelen, bevelen wij aan om naast de structuur- en procesindicatoren, meer uitkomstindicatoren te ontwikkelen, gelijkwaardig en in 'partnership' tussen zorgprofessional en patiënt. 